Acta vet. scand. $1986,27,115-123$.

From the National Veterinary Institute, Oslo, Norway.

\title{
COLICIN RESISTANCE IN RELATION TO PATHOGENICITY FACTORS IN STRAINS OF ESCHERICHIA COLI ISOLATED FROM THE INTESTINAL TRACT OF PIGLETS
}

By

Berit K. Djфnne

\begin{abstract}
DJØNNE, BERIT K.: Colicin resistance in relation to pathogenicity factors in strains of Escherichia coli isolated from the intestinal tract of piglets. Acta vet. scand. 1986, 27, 115-123. - Three hundred and fifteen E. coli strains isolated from the intestine of piglets were examined for $\mathrm{K}$-antigens 88 and 99, enterotoxin production and colicin resistance. Of these strains 308 belonged to one of 3 following different groups: Group 1: 0149, K88, producing heat-labile (LT) and heat-stable (ST) enterotoxins, group 2: O64, K99, producing ST, and group 3: variable $\mathrm{O}$-antigens, no $\mathrm{K}$-antigens or enterotoxin production.

Almost $100 \%$ of the E. coli strains were found to be resistant to colicins $\mathrm{E}_{1}, \mathrm{E}_{3}, \mathrm{Ia}, \mathrm{H}$ and $\mathrm{D}+\mathrm{X}$. Resistance to colicins $\mathrm{E}_{2}, \mathrm{~B}+\mathrm{M}, \mathrm{V}$ and $\mathrm{K}+\mathrm{X}$ were found in $91.7 \%, 43.8 \%, 49.8 \%$ and $62.2 \%$ respectively.

E. coli strains in group 1 were always resistant to colicin $\mathrm{E}_{2}$, while about $87 \%$ of the other strains were resistant to this colicin. E. coli strains in group 2 were more often resistant to colicin $\mathrm{B}+\mathrm{M}$, $\mathrm{V}$ and $\mathrm{K}+\mathrm{X}(65 \%, 94 \%, 83 \%)$ than strains in group $1(37 \%, 24 \%$, $64 \%)$ and strains in group $3(37 \%, 52 \%, 46 \%)$.

E. coli strains in group 2 showed a high degree of multiresistance, $45.1 \%$ of the strains being resistant to all of the 9 colicins. About $10 \%$ of the other strains were resistant to all of the 9 colicins.

E. coli strains harbouring the enteropathogenicity factors K99 antigen and ST production, showed a higher degree of colicin resistance than both the E. coli strains with K88 antigen and ST and LT production, and the E. coli strains lacking enteropathogenicity factors.
\end{abstract}

enterotoxins; K-antigens; enteropathogenicity factors; virulence factors.

Colicins are bacteriocidal proteins produced by Escherichia coli (E. coli) and some other organisms within the family Enterobacteriaceae. About 20 different colicins have been demonstrated (Fredericq 1965), all acting against E. coli or closely 
related bacteria (Bull \& Meadow 1978). Inactivation of RNA and degradation of DNA, as well as inhibition of oxydative phosphorylation, are some of the mechanisms involved in the effect of colicins on susceptible bacteria (Reeves 1968, Bowman et al. 1971, Smarda 1975).

Strains of E. coli can be resistant to several colicins, and multiple resistance are often found. An organism can be resistant to colicins in different ways (Glass 1982). The strain can loose the colicin receptor, or the strain can bind the colicin, but with no effect on the receptor strain. Resistance to colicins may also be based on the production of immunity protein, a plasmid-coded protein, which protects the strain against the colicin in question.

In a previous investigation (Dj申nne 1985), enteropathogenic E. coli strains (harbouring $\mathrm{K}$-antigens 88 or 99 and producing enterotoxins) were found to produce colicin more often than strains where no enteropathogenicity factors were found. It was suggested that colicin production could be of some importance to the enteropathogenicity of E. coli strains.

The aim of the present study was to examine E. coli strains isolated from the intestine of piglets for resistance to different colicins, and to correlate this characteristic to the presence of pathogenicity factors in the same strains.

\section{Piglets}

\section{MATERIALS AND METHODS}

The investigation included 43 piglets between 1 and 14 days of age. Thirty piglets had gross lesions and bacteriological findings corresponding to those seen in neonatal E. coli diarrhea. Thirteen piglets had died because of traumatic lesions.

\section{E. coli strains}

Sampling procedures, bacteriological examination and identification of E. coli strains are described by Djønne (1985). From each piglet 6 to $10 \mathrm{E}$. coli strains were isolated. The strains were examined for 0 -antigens $2,6,8,9,32,45,64,98,101,115$, 124, 125ab, 138, 139, 141, 145, 147, 149 and 157, K-antigens 88 and 99 (Söderlind 1971, Guinèe et al. 1977), production of heatlabile enterotoxin (LT) (Olsvik et al. 1982) and heat-stable enterotoxin (ST) (Dean et al. 1972). 
Demonstration of colicin production and resistance to different colicins

The E. coli strains were examined for resistance to colicins produced by the following 9 type strains:

CA62 = E. coli (Paracoli), producing colicin $\mathrm{E}_{1}{ }^{\star}$

CA38 = E. coli, producing colicin $\mathbf{E}_{3}{ }^{*}$

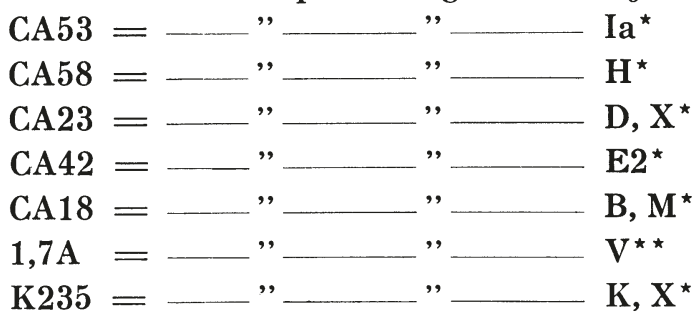

The isolated E. coli strains were examined for resistance to the different colicins by the following method: Spot cultures of the 9 type strains were made on blood agar, incubated at $37^{\circ} \mathrm{C}$ for $20 \mathrm{~h}$, killed by exposure to chloroform vapour and left at room temperature for $30 \mathrm{~min}$ to remove residual chloroform. One colony of the E. coli strain to be tested for colicin resistance was diluted in $5 \mathrm{ml}$ of saline, and poured on to the plates with the chloroform-killed type strains. Excess material was removed, and the plates were kept at room temperature for $1-2 \mathrm{~h}$, then incubated at $37^{\circ} \mathrm{C}$ for about $20 \mathrm{~h}$. If the growth of the strain was close to the colicin-producnig type strain, the strain was regarded as being resistant against the colicin concerned. If there was an inhibition zone of $1 \mathrm{~mm}$ or more, the strain was regarded as being susceptible.

\section{Statistical methods}

The Chi-square test was used for statistical significance testing.

\section{RESULTS}

A total of 315 E. coli strains were examined. Of these strains 308 were categorized into one of 3 groups: Group 1: E. coli 0149, K88, producing LT and ST ( $\mathrm{n}=127)$, group 2: E. coli O64, K99,

* Kindly supplied by Dr. P. Fredericq, Institut de Microbiologie et Hygiène de l'Universitè, Liège, Belgium.

* From the Norwegian College of Veterinary Medicine, Oslo. 
producing $\mathrm{ST}(\mathrm{n}=71)$ or group 3: E. coli strains with 0 -antigen $8,45,64,141,147,157$ or no 0 -antigens demonstrated, and with neither K-antigens nor enterotoxin production $(n=110)$. The other 7 strains showed independently different characteristics, which were also inconsistent with the characteristics of the strains in groups 1, 2 and 3. All E. coli strains in groups 1 and 2 were isolated from piglets which had died from neonatal diarrhea, while the strains in group 3 came from piglets with traumatic lesions.

The proportion of the $308 \mathrm{E}$. coli strains that were resistant to colicin $\mathrm{E}_{1}, \mathrm{E}_{3}, \mathrm{Ia}, \mathrm{H}, \mathrm{D}+\mathrm{X}, \mathrm{E}_{2}, \mathrm{~B}+\mathrm{M}, \mathrm{V}$ and $\mathrm{K}+\mathrm{X}$ is presented in Table 1.

Table 1. Colicin resistance in 308 E. coli strains with different patterns regarding $\mathrm{O}$-antigens, $\mathrm{K}$-antigens and enterotoxin production.

\begin{tabular}{|c|c|c|c|c|}
\hline \multirow[t]{2}{*}{ Colicin } & \multicolumn{4}{|c|}{ Percentage of resistant strains in the various groups of E. coli } \\
\hline & Group $1(=127)$ & Group $2(n=71)$ & Group $3(\mathrm{n}=110)$ & Total $(n=308)$ \\
\hline$E_{1}$ & 99.2 & 100 & 98.2 & 99.0 \\
\hline $\mathbf{E}_{3}$ & 96.1 & 100 & 92.7 & 95.2 \\
\hline $\mathrm{Ia}^{3}$ & 92.9 & 100 & 98.2 & 96.2 \\
\hline $\mathbf{H}$ & 99.2 & 100 & 98.2 & 99.0 \\
\hline $\mathbf{D}+\mathbf{X}$ & 99.2 & 100 & 99.1 & 98.4 \\
\hline $\mathbf{E}_{2}$ & $100 \mathbf{a}^{1}$ & $87.3^{\mathbf{b}}$ & $86.4^{\mathrm{b}}$ & 91.7 \\
\hline $\mathbf{B}+\mathbf{M}$ & 37.4a1 & $64.8^{b}$ & $37.2 \mathrm{a}$ & 43.8 \\
\hline V & $23.6^{\mathrm{a} 1}$ & $94.4^{\mathrm{b}}$ & $51.8 \mathrm{c}$ & 49.8 \\
\hline $\mathbf{K}+\mathbf{X}$ & $63.8^{\mathrm{a}^{2}}$ & $83.1^{b}$ & $46.4 \mathrm{c}$ & 62.2 \\
\hline
\end{tabular}

1 Different letter indicates a statistically significant difference between the groups $\mathrm{P}<0.001$.

2 Different letter indicates a statistically significant difference between the groups $\mathrm{P}<0.01$.

Group 1: 0149, K88, LT and ST production.

Group 2: 064, K99, ST production.

Group 3: Variable O-antigens demonstrated, no K88 and K99, no enterotoxin production.

Resistance to colicins $\mathrm{E}_{1}, \mathrm{E}_{3}, \mathrm{Ia}, \mathrm{H}$ and $\mathrm{D}+\mathrm{X}$ were found in approx. 93-99\% of the strains. All the strains in group 2 were resistant to these colicins, while in group 1 and 3, a few suscepible strains were demonstrated. There was, however, no statistically significant associations between resistance to any of these 5 colicins and the occurrence of pathogenicity factors ( $\mathrm{K}$-antigens 88 and 99 or enterotoxin production). 
Regarding resistance to colicins $\mathrm{E}_{2}, \mathrm{~B}+\mathrm{M}, \mathrm{V}$ and $\mathrm{K}+\mathrm{X}$, there were statistically significant differences between the three groups of E. coli strains. The strains in group 1, harbouring K88 antigen, were more often resistant to colicin $E_{2}$ than the other strains. The E. coli strains with K99 antigen (group 2) were more often resistant to colicin $B+M, V$ and $K+X$ than the strains in group 1 and 3.

Statistically significant associations were demonstrated between resistance to one of the colicins and the production of enterotoxins in the $308 \mathrm{E}$. coli strains tested $(\mathrm{P}<0.005)$. Strains with detectable ST production were more often resistant to colicin $\mathrm{K}+\mathrm{X}$ than strains where no enterotoxin production was found. There was no significant difference in resistance to colicin $\mathrm{E}_{2}, \mathrm{~B}+\mathrm{M}$ and $\mathrm{V}$ between $\mathrm{ST}$ producing and non ST producing E. coli strains. LT production was only found in the strains in group 1, and LT production therefore showed the same correlations with colicin resistance as the $\mathrm{K} 88$ antigen.

None of the $308 \mathrm{E}$. coli strains were resistant to only one of the 9 colicins tested. Most of the strains showed a high degree of multiresistance (Table 2). Multiresistance was commonly found in E. coli strains of group 2, $45.1 \%$ being resistant to all the 9 colicins tested. About $10 \%$ of the strains in group 1 and group 3 were resistant to all the nine colicins. There was a statistically significant difference in multiresistance between the strains in group 2 and the other strains $(\mathrm{P}<0.001)$.

T a b l e 2. Multiple colicin resistance in $308 \mathrm{E}$. coli strains with different patterns regarding $\mathrm{O}$-antigens, $\mathrm{K}$-antigens and enterotoxin production.

\begin{tabular}{lccc}
\hline Group & \multicolumn{3}{c}{ Percentage of E. coli strains being resistant to } \\
\cline { 2 - 4 } & 9 colicins & 8 colicins & less than 8 colicins \\
\hline $\begin{array}{l}\text { Group 1: } \\
(\mathrm{n}=127)\end{array}$ & 9.4 & 22.8 & 67.7 \\
$\begin{array}{l}\text { Group 2: } \\
(\mathrm{n}=71)\end{array}$ & 45.1 & 43.7 & 11.3 \\
$\begin{array}{l}\text { Group 3: } \\
(\mathrm{n}=112)\end{array}$ & 10.7 & 31.5 & 58.0 \\
\hline
\end{tabular}

Group 1: 0149, K88, LT and ST production.

Group 2: 064, K99, ST production.

Group 3: Various O-antigens, no K88 or K99, no enterotoxin production. 


\section{DISCUSSION}

In the present investigation, resistance to colicin $\mathrm{E}_{1}, \mathrm{E}_{3}$, Ia, $\mathrm{H}$ or $\mathrm{D}+\mathrm{X}$ was demonstrated in approx. 93-99\% of the $308 \mathrm{E}$. coli strains tested. There was no relationship between resistance to these colicins and the occurrence of pathogenicity factors in the strains tested. Resistance to the colicins $\mathrm{E}_{2}, \mathrm{~B}+\mathrm{M}, \mathrm{V}$ or $\mathrm{K}+\mathrm{X}$ was demonstrated in approx. $40 \%$ to $90 \%$ of the E. coli strains tested. Strains in group 2 (O64, K99, $\mathrm{ST}^{+}$) showed a high degree of colicin resistance to colicin $\mathrm{B}+\mathrm{M}, \mathrm{V}$ and $\mathrm{K}+\mathrm{X}$, compared to strains in group $1\left(\mathrm{O} 149, \mathrm{K88}, \mathrm{LT}^{+}, \mathrm{ST}^{+}\right)$and strains in group 3 (various $\mathrm{O}$-antigens neither $\mathrm{K}$-antigens nor enterotoxin production). This resistance seemed to be correlated to the presence of K99 antigen in the strains. There is little information available on the colicin resistance in strains harbouring K99 antigen, and the present findings are therefore difficult to relate to similar studies.

E. coli strains in group 1 were always resistant to colicin $\mathrm{E}_{2}$, while resistance to this colicin was found in approx. $87 \%$ of the strains in group 2 and 3 . Resistance to colicin $\mathrm{E}_{2}$ was, however, so common in all the 308 strains that this correlation is probably of little importance. Strains in group 1 showed a higher degree of resistance to colicin $\mathrm{K}+\mathrm{X}$ than strains in group 3 , the reason for this correlation perhaps being that colicin $K+X$ resistance is correlated to ST production. With the exception of resistance to colicin $\mathrm{K}+\mathrm{X}$ there seemed to be no correlation between colicin resistance and the production of ST.

Also concerning multiresistance to colicins, the E. coli strains of the O-group 64 harbouring $\mathrm{K99}$ antigen and producing ST seemed to behave significantly different from the E. coli strains with other characteristics. Approx. $45 \%$ of the former strains were resistant to all the colicins tested. In group 1 and 3 the frequency of strains showing multiresistance was significantly lower. Ciosek \& Truszczynski (1971) investigated multiresistance to 15 colicins in E. coli strains with $\mathrm{O}$-antigen 149 . They found that $74.5 \%$ of the strains were resistant to all the colicins tested. In the present investigation only about $10 \%$ of the strains with this $\mathrm{O}$-antigen (group 1 ) were resistant to all the nine colicins. The colicin producing type strains used by Ciosek \& Truszczynski differed, however, from those used in the present study. E. coli strains may also have different characteristics depending on their geographical origin. 
Colicin production has been found to be plasmid mediated (Fredericq 1957). Genes coding for K-antigens 88 and 99 and enterotoxin production are also located on plasmids (Ørskov \& Ørskov 1966, Smith \& Linggood 1971). Some reports also exist on plasmids simultaneously coding for colicin production and enteropathogenicity factors (Williams et al. 1978, Franklin et al. 1981, Harnett \& Gyles 1985). In this investigation, the enteropathogenic E. coli strains in group $2\left(\mathrm{O} 64, \mathrm{~K} 99, \mathrm{ST}^{+}\right)$showed a higher degree of colicin resistance than both the enteropathogenic strains in group $1\left(\mathrm{O} 149, \mathrm{~K} 88, \mathrm{ST}^{+}, \mathrm{LT}^{+}\right)$and the strains lacking enteropathogenicity factors. The possibility that this correlation might be plasmid mediated, needs to be elucidated by further studies.

In a previous investigation (Djønne 1985), colicin production was found to correlate with enteropathogenicity factors (K-antigens 88 and 99 and ST production). If colicins have any influence on the microbial flora in the intestine, the strains with colicin production and a high degree of colicin resistance might outnumber colicin sensitive strains. There are very few reports on the effect of colicins in the intestine. Some studies, however, indicate that colicins have a function in establishing the microbial flora in the intestine of piglets (Willinger \& Trcka 1973). It has been shown that colicins are inactivated by the presence of trypsin, and colicins were therefore found to be inactive in the intestinal fluid of a three month old pig, in which the trypsin content was about $2800 \mathrm{ug} / \mathrm{ml}$ intestinal fluid (de Alwis \& Thomlinson 1975). In newborn piglets, however, the concentration of proteolytic enzymes is low, and their activity might be further reduced by inhibitors in colostrum (Tizard 1982). It is therefore possible that colicin production and colicin resistance are of importance in establishing infection with enteropathogenic E. coli in newborn piglets, and that this influence is reduced at the time when normal physiological functions of the digestive tract is established.

\section{ACKNOWLEDGEMENTS}

The excellent technical assistance of Gry Jaeger and Mona Gjestvang is highly appreciated.

\section{REFERENCES}

Bowman, C. M., J. E. Dahlberg, T. Ikemura, J. Konisky \& M. Nomura: Specific inactivation of $16 \mathrm{~S}$ ribosomal RNA induced by colicin E3 in vivo. Proc. nat. Acad. Sci. (Wash.) 1971, 68, 964-968. 
Bull, A. T. \& P. M. Meadow: Companion to microbiology: Selected topics for further studies. Longman, London 1978, VII, 109126.

Ciosek, D. \& M. Truszczynski: Pathogenic properties and the occurrence of capsular antigens, biochemical characteristics and susceptibility to colicins in Escherichia coli strains of group 0149. Bull. Vet. Inst. Pulawy 1971, 15, 105-112.

de Alwis, M. C. L. \& J. R. Thomlinson: Some factors influencing colicin activity between pathogenic and commensal Escherichia coli from the pig. Res. Vet. Sci. 1975, 19, 63-70.

Dean, A. G., Yi-Chuan Ching, R. G. Williams \& L. B. Harden: Test for Escherichia coli enterotoxin using infant mice: Application in a study of diarrhea in children in Honolulu. J. inf. Dis. 1972, $125,407-411$.

Djønne, $B$. $K$.: Colicin production in relation to pathogenicity factors in strains of Escherichia coli isolated from the intestinal tract of piglets. Acta vet. scand. 1985, 26, 145-152.

Franklin, A., O. Söderlind \& R. Möllby: Plasmids coding for enterotoxins, K88 antigen and colicins in porcine Escherichia coli strains of O-group 149. Med. Microbiol. Immunol. 1981, 170, $63-72$.

Fredericq, P.: Colicins. Ann. Rev. Microbiol. 1957, 11, 7-22.

Fredericq, P.: A note on the classification of colicins. Zbl. Bakt. Abt. I. Orig. 1965, 196, 140-142.

Glass, R. E.: Gene Function. E. coli and its heritable elements. Croom Helm Ltd, London 1982, p. 187-191.

Guinèe, P. A. M., J. Veldkamp \& W. H. Jansen: Improved Minca medium for the detection of K99 antigen in calf enterotoxigenic strains of Escherichia coli. Infect. Immun. 1977, 15, 676-678.

Harnett, N. M. \& C. L. Gyles: Linkage of genes for heat-stable enterotoxin, drug resistance, K99 antigen, and colicin in bovine and porcine strains of enterotoxigenic Escherichia coli. Amer. J. vet. Res. 1985, 46, 428-433.

Olsvik, Ø., O. T. Hushovd, B. P. Berdal, T. Bergan \& M. Mathiesen: Production of enterotoxin by Escherichia coli at four, twentytwo and hirty-seven degrees centigrade. Eur. J. clin. Microbiol. 1982, 1, 12-16.

Reeves, P.: Mode of action of colicins of types $\mathrm{E}_{1}, \mathrm{E}_{2}, \mathrm{E}_{3}$ and K. J. Bacteriol. 1968, 96, 1700-1703.

Smarda, J.: Novel approaches to the mode of action of colicins. Folia Microbiol. 1975, 20, 264-271.

Smith, H. W. \& M. A. Linggood: Observations on the pathogenic properties of the K88, Hly and Ent plasmids of Escherichia coli with particular reference to porcine diarrhoea. J. med. Microbiol. 1971, 4, 467-485.

Söderlind, O.: Studies on Escherichia coli in pigs. II. Serological investigations. Zbl. Vet. Med. B. 1971, 18, 569-590. 
Tizard, I.: An Introduction to Veterinary Immunology. W. B. Saunders Company, 2nd ed. London 1982, p. 170-173.

Williams, P. H., M. I. Sedgwick, N. Evans, P. J. Turner, R. H. George \& A. S. McNeish: Adherence of an enteropathogenic strain of Escherichia coli to human intestinal mucosa is mediated by a colicinogenic conjugative plasmid. Infect. Immun. 1978, 22, $393-402$.

Willinger, H. \& J. Trcka: Vorkommen colicinogener E. coli in der Darmflora des Ferkels. (Incidence of colicinogenic E. coli in the gut flora of healthy pigs). Zbl. Bakt., I. Abt. Orig. A 1973, $225,406-415$.

Ørskov, I. \& F. Ørskov: Episom-carried surface antigen K88 of Escherichia coli. J. Bacteriol. 1966, 91, 69-75.

\section{SAMMENDRAG}

Colicin resistens relatert til enteropatogenitets faktorer hos stammer av Escherichia coli isolert fra tarmkanalen hos spedgris.

Forekomst av K-antigen 88 og 99, enterotoxin produksjon og colicin resistens ble unders $\phi k t$ hos $315 \mathrm{E}$. coli-stammer isolert fra tynntarmen hos spedgris. Av disse stammene tilhørte 308 stammer en av følgende tre grupper: Gruppe 1: $0149, \mathrm{~K} 88$, produksjon av både varmelabilt (LT) og varmestabilt (ST) enterotoxin, gruppe 2: 064, K99, ST produksjon eller gruppe 3: varierende $O$ antigen uten påvisbare $\mathrm{K}$-antigen eller enterotoxin produksjon.

Tilnærmet $100 \%$ av alle stammene var resistente mot colicinene $\mathrm{E}_{1}, \mathrm{E}_{3}, \mathrm{Ia}, \mathrm{H}$ og $\mathrm{D}+\mathrm{X}$. Resistens mot colicinene $\mathrm{E}_{2}, \mathrm{~B}+\mathrm{M}, \mathrm{V}$ og $\mathrm{K}+\mathrm{X}$ ble påvist hos henholdsvis $91,7 \%, 43,8 \%, 49,8 \%$ og $62,2 \%$ av stammene.

Alle E. coli-stammer i gruppe 1 var resistente mot colicin $\mathrm{E}_{2}$, mens omtrent $87 \%$ av de resterende stammer var resistente mot colicin $\mathrm{E}_{2}$. Stammer $\mathrm{i}$ gruppe 2 var oftere resistente mot colicin $\mathrm{B}+\mathrm{M}$, $\mathrm{V}$ og $\mathrm{K}+\mathrm{X}(65 \%, 94 \%, 83 \%)$ enn stammer i gruppe $1(37 \%, 24 \%$, $64 \%)$ og stammer i gruppe $3(37 \%, 52 \%, 46 \%)$.

E. coli-stammer i gruppe 2 var ofte resistente mot flere coliciner, $45,1 \%$ av disse stammene var resistente mot alle de ni unders $\varnothing \mathrm{kte}$ colicinene. Tilnærmet $10 \%$ av de resterende stammene var resistente mot alle ni coliciner.

E. coli-stammer med enteropatogenitets faktorene K99 antigen og ST produksjon var i st $\varnothing$ rre grad resistente mot coliciner enn stammer som hadde K88 antigen, ST og LT produksjon og stammer uten enteropatogenitets faktorer.

(Received December 30, 1985).

Reprints may be requested from: Berit K. Djønne, the National Veterinary Institute, P. O. Box 8156 Dep., N-0033 Oslo 1, Norway. 